\title{
Dramaty (nie)zwierzęce w teatrze lalek dla dzieci
}

\section{(Non)animal plays in puppet theatre for children}

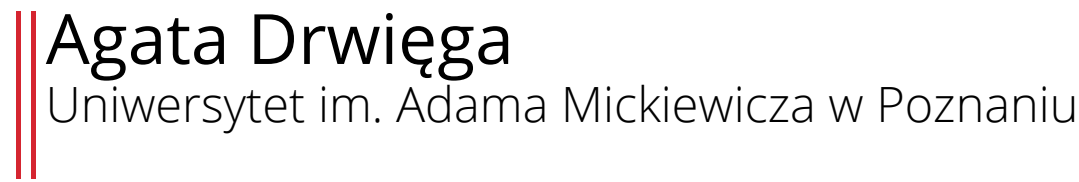

\begin{abstract}
Agata Drwiega in her paper investigates how animals are present in contemporary drama for children and in Polish puppet theatre. Pieces in which animals are treated as if they were humans (in both negative and positive sense) are discussed. Investigated dramas include A. Wiktorowska-Chmielewska's Malwinka in the Bird's Kingdom and M. Guśniowska's Marvin. Here, animals are generally treated as objects, and their real nature is not relevant for the content of drama. Texts concentrate on certain aspects of animal nature but also include animals which still undergo anthropomorphism (for example in: M. Guśniowska's The Snake, M. Prześluga's Beak in Beak and M. Baltscheit's One Day Only). The last performance discussed in the paper is Baltic. A Dog on an Ice Floe directed by R. Wicza-Pokojski which tells the story of an animal but retains its subjectivity and places it at the same level as human experience. In general, the artist's approach to animals is manifested by not only the puppet's looks, but also by their role in the show. Puppets of less popular animals (e.g. pigeons, snakes or mayflies) often do not resemble original organisms, in contrast to puppets of mammals (e.g. cats, dogs). In the same time, non-human characters are almost always anthropomorphised or infantilized.
\end{abstract}

Key words: puppet theatre; children's theatre; puppet; animals on stage

Streszczenie: Agata Drwięga analizuje, w jaki sposób zwierzęta są obecne we współczesnych dramatach dla dzieci oraz na scenach polskich teatrów lalek. Autorka wspomina sztuki (Malwinka w Ptasim Królestwie A. Wiktorowskiej-Chmielewskiej i Marvin M. Guśniowskiej), które cechuje przedmiotowe podejście do zwierząt. Swoją uwagę koncentruje przede wszystkim na tekstach eksponujących wybrane aspekty zwierzęcej natury, jednak nieuciekających od antropomorfizacji bohaterów (Dziób $w$ dziób M. Prześlugi, Wą̇ M. Guśniowskiej i Tylko jeden dzień M. Baltscheita). Ostatnim przedmiotem analizy jest spektakl Baltic. Pies na krze R. Wiczy-Pokojskiego, gdzie opowiedziano historię zwierzęcia, zachowując odrębność jego natury, jednocześnie stawiając je na równi z człowiekiem. Podejście realizatorów do kwestii zwierzęcej objawia się zarówno przez wygląd lalek, jak ich rolę w spektaklu. Animanty zwierząt niepopularnych (takich jak gołąb, wąż czy jętka) rzadziej niż lalki ssaków (kot, pies) wykazują podobieństwo do swoich, występujących 
w naturze, pierwowzorów. Jednocześnie lalki bohaterów nie-ludzkich niemal zawsze upodabnia się do ludzi lub infantylizuje.

Słowa klucze: teatr lalek; teatr dla dzieci; animant; zwierzęta w teatrze

Zwierzęta pojawiają się na scenach profesjonalnych teatrów dla dzieci od czasów ich powstania. Wystarczy spojrzeć na spisy postaci w dramatach Marii Kownackiej związanej z warszawskim Teatrem Baj (jedyną przedwojenną sceną dla dzieci w Polsce), by zorientować się, że bohaterowie zwierzęcy występowali w nich równie często, co ludzcy i fantastyczni. W powojniu, które z jednej strony przyniosło gwałtowny rozwój i profesjonalizację teatrów lalek, z drugiej zaś ich centralizację i podporządkowanie repertuaru ideom socrealizmu, ta sytuacja nie uległa zmianie. Teatrom lalek przypisano widzów dziecięcych, a tym ostatnim teatralne bajki zwierzęce i magiczne.

$\mathrm{W}$ czasach stalinizmu repertuar składający się z rosyjskich bajek był alternatywą dla socrealistycznych widowisk propagandowych, nic zatem dziwnego, że chętnie sięgano po klasykę. Jednak zwierzęta nie zniknęły z polskich scen teatrów dla dzieci wraz ze śmiercią Józefa Stalina. W 1968 roku na łamach miesięcznika „Dialog” ukazał się tekst Kilka myśli o teatrze dla najmłodszych pióra Andrzeja Falkiewicza. Diagnozując w nim zarówno sytuację ówczesnych teatrów lalek, jak i stosunek twórców do młodych widzów, autor zwrócił uwagę na pewne prawidłowości repertuarowe:

Dla najmłodszych często przeznaczamy bajeczkę. Ta bajeczka jest tworem złożonym, który powstał ze skrzyżowania dawnej bajki z obyczajową obserwacją współczesną i z łatwo czytelnym morałem. Często wychowania dzieci podejmują się zwierzęta. Nie to jednak jest ważne, że zwierzęta w bajeczkach są realistycznie ludzkie, ale to, że zachowują się podobnie jak domownicy dziecka, że mają te same kłopoty, że wplątują się w znane z domu awantury, że wygłaszają podobne i zawsze bardzo nudne nauki (Falkiewicz 1968).

Podobnie jest i dziś. Zwierzęta spotyka się na scenach oraz we współczesnej dramaturgii dla młodych odbiorców znacznie częściej niż ludzi, choć nachalne morały przestały być regułą. Gęsi z depresją, węże marzące o posiadaniu kończyn, wrony szukające kapelusza czy lisy próbujące przechytrzyć śmierć występują w rolach głównych pośród tłumnie pojawiających się w drugim planie ssaków, ptaków, gadów, płazów, ryb i owadów. Wykorzystywanie zwierząt w sposób, jaki opisał to prawie ćwierć wieku temu Falkiewicz, nadal jest najpopularniejszą formą ich obecności na scenie, choć zdarzają się dramaty i spektakle, których autorzy, zainspirowani jakąś cząstką zwierzęcej natury, uczynili ją osią fabularną swoich historii. Skutkiem takich zabiegów zazwyczaj nie są utwory (dramatyczne ani sceniczne), świadczące o podmiotowym postrzeganiu zwierząt, a przez to wyznaczające nowe kierunki w ich przedstawianiu ${ }^{1}$.

\footnotetext{
${ }^{1}$ Postrzeganie i przedstawianie podmiotowe tj. przeciwstawne przedmiotowemu; szanujące naturę taką, jaka jest; nie tylko nieuczłowieczające zwierząt, ale też nieprzypisujące im właściwości, których nie posiadają. Autor reprezentujący tę postawę odnosi wybrane cechy gatunkowe do doświadczenia ludzkiego przez zbudowanie paraleli pozbawionej wartościowania.
} 
Niemniej jednak od lat niesłabnąca popularność dramatycznych bajek zwierzęcych zasługuje na omówienie. Dokonam go, posługując się przykładami przede wszystkim polskich sztuk oraz spektakli dla dzieci, powstałych na przestrzeni ostatniej dekady. Skupię się na dramatach, których autorzy starali się wydobyć zwierzęcość swoich postaci i odniosę ten aspekt do ich późniejszych realizacji. Wybór analizowanych utworów wynikał z moich doświadczeń odbiorczych poprzedzonych lekturą tekstu. Spektakl Baltic stanowi wyjątek od tej reguły - nie czytałam wcześniej książki Barbary Gawryluk i nie szukałam jej scenicznej adaptacji. W tym przypadku teatr był pierwszy.

\section{Bajki (nie) o zwierzętach}

Opowiadanie historii prawdziwych zwierząt nie jest tym, co najbardziej interesuje współczesnych dramatopisarzy i reżyserów. Daleko większą popularnością cieszą się dramatyczne bajki zwierzęce, które mówią o problemach uniwersalnych $\mathrm{z}$ humanistycznego punktu widzenia. Ingerencja $\mathrm{w}$ naturę bohaterów nie kończy się na prostej antropomorfizacji, polegającej na przypisywaniu im ludzkich umiejętności, cech charakteru czy narzuceniu kategorii moralnych. Bywa, że autorzy ignorują fakt, że postaci zwierzęce i ludzkie potrzebują odmiennych środków wyrazu lub poddają zwierzęta wtórnej animalizacji, obdarzając jednego bohatera cechami charakterystycznymi dla różnych gatunków.

W dramatach pojawiają się zatem zwierzęta, które nie tylko mówią (w przypadku tego rodzaju literackiego wydaje się to nieuniknione) czy noszą popularne ludzkie imiona i nazwiska gatunkowe (np. puchacz Teofil Piórkowski, królik Zenon Królikowski itp.); w didaskaliach przypisuje się im mowę ciała właściwą homo sapiens, a także zachowania społeczne i kulturowe. Zwierzęta mieszkają w domkach jednorodzinnych, spędzają czas na placach zabaw, pracują w urzędach, noszą i kupują ubrania. Nawet jeśli autor podejmuje decyzję o umieszczeniu akcji „na łonie natury”, wybór ten nie jest równoznaczny $\mathrm{z}$ zachowaniem zasad panujących $\mathrm{w}$ danym ekosystemie. Na przykład w Malwince w Ptasim Królestwie Agnieszki Wiktorowskiej-Chmielewskiej w tym samym lesie spotykają się ptaki zamieszkujące obszary leśne, rolnicze i górskie, migrujące i osiadłe, nocne i dzienne. Ich charakterystyczne zachowania gatunkowe nie są istotne dla rozwoju fabuły ani akcji, a zwierzęta wymienione przez autorkę można by zastąpić dowolnie wybranymi ptakami, ssakami czy innymi przedstawicielami królestwa zwierząt. Jedynym bohaterem, którego przynależność gatunkowa wydaje się mieć w tej historii znaczenie, jest migrujący bocian Kajetan. Przede wszystkim jednak liczy się fakt, że to on znajduje w lesie ludzkie niemowlę, którym najpierw się opiekuje, a potem oddaje rodzicom. Zakończeniem historii jest morał przestrzegający przed szukaniem przyjaciół daleko, bo przeoczymy tych znajdujących się najbliżej. Podobną naukę 
można wygłosić, używając dowolnie wybranych postaci, a fakt, że głównym bohaterem uczyniono akurat bociana, jest ważny z powodu kulturowego wyobrażenia, nie służy jednak ani wyjaśnieniu przyczyn powstania stereotypu, ani go nie komentuje. Bocian niosący w dziobie dziecko pojawia się w tekście jako nic niewnoszący do treści, ikoniczny cytat, a naturalne zachowanie tych ptaków ma drugorzędne znaczenie.

Stereotypowe (więc często niezgodne $\mathrm{z}$ prawami przyrody) myślenie o danym zwierzęciu to często główny lub jedyny czynnik determinujący wybór przedstawiciela jakiegoś gatunku na bohatera sztuki. I tak bociany najczęściej występują w roli kurierów roznoszących dzieci, jeże dźwigają na plecach jabłka, a wilki są czarnymi charakterami, które ośmiesza się przez parodiowanie fragmentów baśni o Czerwonym Kapturku. W teatrze dla dzieci z jakichś powodów nie ma miejsca na rzeczową polemikę ani ze znaczeniami alegorycznymi, baśniowymi czy mitycznymi, ani ze znanymi obrazkami kulturowymi.

Przykładem wtórnej animalizacji zwierzęcego bohatera jest występujący w Marvinie Marty Guśniowskiej motyl Ulisses. Lekko szalony owad, ucieleśniający to, co w życiu nietrwałe, został kontrastowo zestawiony z długowiecznym żółwiem i mającym wkrótce wyginąć dinozaurem - razem tworzą oni przewrotnie spójną galerię osobliwości, których natura napędza zarówno fabułę, jak i akcję utworu. Komizm postaci motyla zbudowano na jego upodobaniu do objadania się, ale najważniejszy z punktu widzenia konstrukcji dramatu jest fakt, że żyje on tylko przez jeden dzień. Zatem dwie główne cechy charakterystyczne danego bohatera wykluczają się z przyrodniczego punktu widzenia. Wiadomo, że istnieją insekty, które w formie dorosłej mogą przetrwać czasem przez kilka godzin, jednak dzieje się tak, ponieważ mają uwsteczniony (nie spełniający swojej funkcji) układ pokarmowy - żyją krótko, bo nie mogą jeść. Motyla, jako atrakcyjny wizualnie symbol ulotnego piękna, dla wzmocnienia efektu jego kruchej egzystencji wyposażono w cechę, którą posiadają inne owady (na przykład jętki), ale żeby nie zasmucać odbiorcy, zrobiono z niego komicznego żarłoka.

Trudno nie odnieść wrażenia, że podobne traktowanie przedstawicieli królestwa zwierząt jest uprzedmiotawiające, a odbiorców pozbawia szansy na poznanie ich wyjątkowej i fascynującej natury. W 1986 roku Umberto Eco w eseju zatytułowanym Jak mówić o zwierzętach zwrócił uwagę na ich obraz projektowany przez kulturę masową i przywołał wypadek, jaki zdarzył się wówczas w nowojorskim Central Parku. Grupa chłopców postanowiła wykąpać się w basenie dla niedźwiedzi polarnych i została zaatakowana - dwoje dzieci zginęło. Zdarzenie to wywołało szeroką dyskusję nad ewentualną karą dla drapieżnika. Ostatecznie uznano, że niedźwiedź nie zasługuje na śmierć, a winę za zdarzenie w całości ponoszą ofiary należące do biednej grupy latynoskich imigrantów - jeśli ktoś jest na tyle „głupi i lekkomyślny”, by się kąpać w takim miejscu, to nic dziwnego, że ginie. Eco 
odpowiedzialnością za tragedię obarcza jednak popularny przekaz dotyczący zwierząt:

Chcąc pokazać, że zwierzęta godne są tego, by żyć, uczłowiecza się je i sprowadza do poziomu zdziecinnienia. Nie mówi się, że mają prawo do życia, nawet jeśli zgodnie ze swoją naturą są dzikie i mięsożerne, ale wpaja się szacunek do nich, przedstawiając je jako miłe, zabawne, dobroduszne, życzliwe, mądre i przezorne (Eco 1986, 67).

Choć Eco broniąc zwierzęcości zwierząt, sam przypisuje im zachowania typowo ludzkie (pisze m.in. o histerycznej naturze koni, głupocie ciem i pozbawionych fantazji mrówkach), wymowa jego eseju nic na tym nie traci. Spostrzeżenie sformułowane trzydzieści lat temu jest adekwatne nie tylko jeśli chodzi o reklamy, filmy animowane czy popularną literaturę, ale także znajduje swoje potwierdzenie we współczesnym teatrze i dramacie dla dzieci. Zwierzęta nader często traktuje się jak poręczne gadżety, jednocześnie pozbawiając je tego, co stanowi o ich naturze. Na szczęście nie zawsze przybiera to tak radykalną formę.

\section{Jak to jest być wołem piżmowym?}

Zaczynając od postawienia tego pytania, Mikołaj Golachowski, biolog, autor książki Czochrałem antarktycznego słonia wyjaśnia pojęcie umweltu, czyli „bardzo subiektywnie postrzeganego «otoczenia ja»” (Golachowski 2016, 246), indywidualnej perspektywy, z jakiej każde stworzenie odbiera otaczający je świat. Na przykład ta sama łąka z punktu widzenia mrówki, skowronka czy sarny to trzy zupełnie różne światy. Książka Golachowskiego ukazuje, jak daleko człowiek, wykorzystując wiedzę przyrodniczą i kierując się empatią, może posunąć się w próbach zrównania doświadczeń zwierzęcych z ludzkimi. Jednocześnie autor często podkreśla niemożność utożsamienia obu perspektyw.

Dramaty, których bohaterami są zwierzęta, w rzeczywistości opowiadają historie ludzi. Wiedza na temat pojawiających się w tekście ssaków, ptaków itp. rzadko ma podłoże przyrodnicze, a pointa dotyczy wartości uniwersalnych z perspektywy humanistycznej. Jednak dramatopisarze, chcąc w ten sposób wypowiedzieć się na jakiś temat ważny z punktu widzenia człowieka, często podejmują próby przyjęcia perspektywy swoich postaci. W tym celu używają rozmaitych stylizacji językowych, budują konflikt dramatyczny wokół wybranej cechy charakterystycznej danego bohatera i tworzą sytuacje paralelne do tych, które znamy z naszego, ludzkiego doświadczenia.

Przykładem tekstu wyjątkowo trafnie ukazującego taki fikcyjny umwelt gołębi żyjących na miejskim podwórku jest Dziób w dziób Maliny Prześlugi. Gdyby czytać ten dramat jako opowieść o ludziach, poznamy historię chuligańskiej bandy jednoczącej się w walce przeciw wspólnemu wrogowi, który w przekonaniu reszty uśmiercił przywódcę grupy. Przeciwnik jest niezwykle silny i konfrontacja z nim grozi niechybną śmiercią, ale dzięki ingerencji 
mądrego obserwatora udaje się nie doprowadzić do honorowego rozlewu krwi. Choć członkowie bandy noszą ludzkie imiona, a ich ptasia natura przejawia się na rozmaite sposoby, paradoksalnie i tak są antropomorfizowani. Ich okrzyki bojowe brzmią: „Kto! Nie! Skacze! Ten! Nie! Gołąb!” lub „Gołąb! Szaro-czerwony!”; w chwilach trwogi modlą się: „Matko wszystkich ptaków, któraś jest w niebie, świergocz imię twoje, wij się gniazdo twoje, bądź wole twoje, chleba naszego daj nam dzisiaj..." (Prześluga 2013, 100); a słownik wulgaryzmów zawiera takie czasowniki jak „przygruchać”, „przypiórzyć”, „obsryndolić” czy „wyćwirtalać”. Wrogiem gołębi jest podwórkowa kotka Dolores, a sprzymierzeńcem, który powstrzymuje krwawą konfrontację - odrzucony przez własną zgraję wróbel Przemek. Gołębie sprawiają wrażenie niezbyt mądrych, walczą z wrogami, „bombardując" ich guanem² i ślepo pędzą tam, gdzie ktoś rozsypie bułkę - są takie, jakimi mieszkańcy miast widzą je na co dzień. Ostatecznie jednak okazują się także istotami zdolnymi do weryfikacji własnych poglądów i przekonań, co stawia je w zaskakująco pozytywnym świetle. Choć brak tu refleksji nad ptasią perspektywą i nie ma wątpliwości, że w gruncie rzeczy historia nie dotyczy gołębi, tekst wyróżnia się wyjątkowo udaną stylizacją sytuacji dramatycznej, dobór postaci jest nieprzypadkowy, a powody takich, a nie innych działań można potraktować jako autorską interpretację zachowań latających mieszkańców miast.

Tekst doczekał się trzech ${ }^{3}$ realizacji na scenach profesjonalnych teatrów lalkowych. Co ciekawe, w każdej występują inne ptaki, choć wszystkie nazywa się gołębiami. Spektakl Zbigniewa Lisowskiego ze scenografią Dariusza Panasa (Teatr Baj Pomorski w Toruniu) zrealizowano w żywym planie z elementami teatru lalek. Na te ostatnie składa się gigantyczna forma ${ }^{4}$ kota i niedające się animować figury ptaków przypominających szare, na wpół oskubane ni to kury, ni gołębie. Lalki są tylko umownymi znakami postaci, a właściwych bohaterów grają aktorzy z umalowanymi na niebiesko ustami, ubrani w podarte bluzy dresowe, spodnie bojówki i ciężkie buty. Odpowiednikiem Dolores jest kobieta w czerwono-czarnym skórzanym trykocie. W spektaklu Lisowskiego zwierzęta są tylko pretekstem do opowiedzenia historii, która rozgrywa się w planie aktorskim i bynajmniej nie traktuje o życiu miejskich gołębi.

Inny pomysł na inscenizację tekstu Prześlugi mieli Ireneusz Maciejewski i Robert Romanowicz (Teatr Animacji w Poznaniu). Reżyser znany ze swego upodobania do lalek muppetowych i gadających ${ }^{5}$, ukrył aktorów za imi-

\footnotetext{
2 Taka strategia obronna jest charakterystyczna dla kwiczołów, ale skojarzenie właśnie z gołębiami nikogo nie zdziwi. Przypisanie jej właśnie tym ptakom można by potraktować jako ich wtórną animalizację lub uznać za przykład konsekwentnego konstruowania postaci wedle interpretacji ogólnie przyjętych wyobrażeń na temat ich pierwowzorów.

3 Zarówno tutaj, jak i w kolejnych akapitach bezpośrednio odnoszę się tylko do tych realizacji, które obejrzałam, ale dla porządku informacji podaję liczbę wszystkich premier.

4 Tam, gdzie to możliwe, pojęć „lalka”, „forma” i „animant” używam zamiennie.

${ }^{5}$ Współczesny teatr lalek charakteryzuje tak duża różnorodność technik animacyjnych, że coraz trudniej o jednoznaczne nazwy form, jakimi posługują się lalkarze. Rzadko już korzysta się z tradycyjnych typów takich jak: kukła, marionetka, jawajka, pacynka itp. Dużo częściej na potrzeby danego
} 
tującym mur parawanem i, konsekwentnie uciekając od wszystkich znajdujących się w dramacie metafor, wystawił historię o ptakach broniących „swoich” parapetów. O tym, że mowa o gołębiach, dowiadujemy się wyłącznie $\mathrm{z}$ tekstu, ponieważ lalki same w sobie najbardziej przypominają papugi. Mają duże głowy, szerokie dzioby i uszyto je z kilkunastu rodzajów materiałów o intensywnych kolorach. Natomiast Dolores jest jak najbardziej kocia - zarówno w wyglądzie, jak i sposobie poruszania. Animują ją cztery osoby: pierwsza trzyma nad parawanem głowę na kiju, druga i trzecia łapy (futrzane rękawy zakończone pazurami); czwarta natomiast prowadzi ogon.

W obu przypadkach mamy do czynienia z podobną tendencją. Forma kota przypomina swój, występujący w naturze, pierwowzór (widząc ją, nie zastanawiamy się, czy to duży domowy kot, czy np. lew lub tygrys), natomiast lalki gołębi pozostają bliżej nieokreślonymi ptakami, nie zaś ich konkretnym gatunkiem. O ile w toruńskiej realizacji dostrzega się inspirację prawdziwymi gołębiami, o tyle w poznańskiej nie - tutaj wybrana forma animacyjna okazała się nadrzędna wobec treści, a realizatorzy tworząc lalki bohaterów, najwyraźniej przyjęli zasadę, że „ptak to ptak”.

Muppety muszą mieć szerokie usta, więc także duże głowy, by zmieściła się w nich dłoń animatora. Dzięki temu wyjątkowo dobrze nawiązują kontakt z publicznością, precyzyjnie „patrząc” na siebie lub widzów. Podstawą ożywienia animantów zawsze jest ruch, a w przypadku lalek gadających najwięcej ruszają się właśnie usta. Ergo, nie da się zbudować niewielkich lalek o proporcjach gołębi i właściwościach muppetów. Jednocześnie trudno pozbyć się wrażenia, że realizatorom wręcz zależało na tym, by lalki nie przypominały gołębi - budowa ciała to jedno, a futrzane, wielobarwne materiały, którymi je obszyto - drugie. Wysiłek został zauważony i doceniony przez widzów: „Gołębie nie wyglądały jak te szare, nieco brudne ptaszyska, które każdego dnia kilka razy stają na mojej drodze (a których panicznie się boję). Były kolorowe, zabawne i wyjątkowo przyjazne (choć charakterne)”6.

Pomimo że takie spojrzenie nadal nie ucieka od perspektywy antropocentrycznej, tekst Prześlugi można by potraktować jako historię właśnie nielubianych miejskich ptaków, która ukazuje ich prawo do bycia takimi, jakie je widzimy, a także pozwala sądzić, że nasze wyobrażenie na ich temat nie musi być zgodne z prawdą. Podobna perspektywa nie interesowała jednak żadnego z reżyserów. Widocznie w teatrze dla dzieci nie ma miejsca dla „szarych, brudnych ptaszysk”.

Zbudowanie paraleli między światem ludzi i zwierząt nie wydaje się trudnym zadaniem, gdy mówimy o gatunkach znanych z codziennego życia;

spektaklu tworzy się ich formy hybrydowe lub wymyśla zupełnie nowe. „Lalki gadające” (ang. talking puppets, określenie, którym posługuje się Neville Tranter w odniesieniu do swoich animantów) w aktorskim żargonie nazywa się też „pyskówkami”, a w literaturze lalkami muppetowymi (od lalek Jima Hensona) lub mimicznymi. Jedną z właściwości zarówno muppetów, jak i lalek mimicznych jest plastyczność ich twarzy (są wykonane z miękkiej, elastycznej gąbki), której to właściwości nie mają twarde, Tranterowe talking puppets. Lalkom ze spektaklu Maciejewskiego bliżej do lalek Trantera niż Hensona, ale akurat to rozróżnienie nie ma znaczenia w przypadku spektaklu, o którym piszę, więc stosuję te nazwy wymiennie.

${ }^{6}$ http://tosimama.blogspot.com/2016/04/dziob-w-dziob.html data dostępu: 23.02.2017. 
ssakach, które z biologicznego punktu widzenia są nam najbliższe, lub w odniesieniu do przedstawicieli tzw. gatunków charyzmatycznych, czyli takich kręgowców, jakie szybko zyskują sympatię ludzi i są wykorzystywane $\mathrm{w}$ kampaniach chroniących przyrodę ${ }^{7}$. Dużo trudniej jest stworzyć wiarygodną i jednocześnie przyjazną postać węża, pająka czy komara. O tym, jak ciężkie jest życie „zwierząt drugiego sortu”, napisał w „Gazecie Wyborczej” Wojciech Mikołuszko, powołując się na wyniki badań australijskich naukowców. Z raportów wynika, że nie tylko laicy, ale również przyrodnicy chętniej angażują się w ochronę stworzeń, które uznają za ładne. („Gazeta Wyborcza” 21.06.2016). O tym, że zwierzęta uchodzące za brzydkie trudniej jest chronić, świadczy przytoczony przez Mikołuszkę przykład amerykańskiego naukowca, który planował założyć nową kolonię węży należących do zagrożonego gatunku Crotalus horridus. Plan się nie powiódł, gdyż żadne racjonalne argumenty nie były w stanie zburzyć oporu mieszkańców tamtego regionu. Niezależnie od tego, czy gad rzeczywiście stanowi zagrożenie dla ludzi, "wąż to wąż - jest brzydki, straszny i zły" (Mikołuszko 2016).

Ich uczuciami przejęła się już raz przywoływana Marta Guśniowska, autorka sztuki Waż. Dramatopisarka przewrotnie wykorzystała budowę ciała gadów jako źródło cierpienia tytułowego bohatera sztuki. Już w pierwszych słowach narrator przedstawia tytułowego bohatera jako „wkurzonego” - zwierzak nie akceptuje braku kończyn, co interpretuje jako własną ułomność, a jego samopoczucia nie poprawia fakt, że co jakiś czas jest obdarowywany rękawiczkami i skarpetkami. Poszukiwania prowadzone wspólnie z chomikiem Chrupusiem (którego na początku próbuje zjeść, ale ostatecznie się z nim zaprzyjaźnia) oraz Gekonem prowadzą do Boga, który każdą istotę uważa za piękną i kompletną, bo powołaną do życia przez Stwórcę z taką samą miłością, lecz wedle innego pomysłu. Historia o samoakceptacji, na poziomie symbolicznym, kończy się przełamaniem biblijnego obrazu węża jako istoty wyklętej. Ponadto, wybierając na głównego bohatera sztuki właśnie przedstawiciela gatunków brzydkich i nielubianych, autorka wystąpiła przeciw ich kulturowemu postrzeganiu.

Wart odnotowania jest fakt, że komizm tej sztuki wynika przede wszystkim z antropocentrycznie postrzeganej natury poszczególnych bohaterów, a wąż, chociaż marudny i opryskliwy, wzbudza współczucie, a nawet sympatię. Dramat jest niezwykle zabawny nie tylko dzięki wartkiej akcji pełnej slapstickowego poczucia humoru, ale także za sprawą nagromadzenia związków frazeologicznych odnoszących się do rąk i nóg. Zabawne perypetie bohaterów wynikają z faktu, że wąż nie może oklaskiwać występu iluzjonisty, wziąć nóg za pas czy spraw w swoje ręce, nie włoży sobie też zakupów pod pachę, ani za nic nie „poręczy”. W kluczowym momencie akcji intryga nie powiedziecie się zaś dlatego, że stojący na czatach Gekon nie 247)

7 Zwanych też gatunkami flagowymi (ang. flagship species), np. panda wielka (Simberlof 1997,

Polonistyka. Innowacje

Numer 5, 2017 
mrugnie okiem ostrzegawczo (nie może, ma zrośnięte powieki), ale dzięki odrzuconemu ogonowi opóźni wyścig.

O ile stworzenie wiarygodnych lalek ptaków może być wyzwaniem dla scenografów, o tyle budowa ciała węży nie nastręcza takich trudności. Jednak, przedstawiając na scenie węża, trzeba zmierzyć się z bohaterem, którego naturalny wygląd i sposób poruszania spotkają się z niechętną reakcją widzów ${ }^{8}$.

Wśród reżyserów, którzy zdecydowali się wystawić sztukę Guśniowskiej, tylko Marek Zákostelecký (także scenograf) odważył się użyć lalki umożliwiającej realistyczny sposób jej animacji. Wąż z Wrocławskiego Teatru Lalek porusza się z właściwą gadom zwinnością oraz ma niepokojący wygląd - małe, nieruchome oczy, trójkątną głowę delikatnie odznaczającą się od reszty tułowia, ruchomą żuchwę i ostrzegawczy zygzak na grzbiecie. Spektakl Zákostelecký'ego mógłby być historią ukazującą piękno „strasznego" węża, ale tak się nie dzieje. Reżyser i scenograf pacynki pozostałych głównych bohaterów ubrał bowiem w kolorowe cylindry i fraki, a akcję utworu umieścił na cyrkowej arenie, więc w miejscu, w którym w szczególny sposób zaprzecza się nie tylko zwierzęcej podmiotowości, ale także godności. W podobnych okolicznościach zapewnienia Boga (granego przez aktora będącego również Narratorem i cyrkowym Konferansjerem) o ważności i pięknie wszystkich stworzeń brzmią co najmniej szyderczo.

W adaptacjach Janusza Ryl-Krystianowskiego ze scenografią Jacka Zagajewskiego (Teatr Animacji w Poznaniu) czy Ireneusza Maciejewskiego w scenografii Barbary Guzik (Teatr Baj Pomorski w Toruniu) wykorzystano niezdarne w ruchach, grube węże-przytulanki. Gada z poznańskiej sceny nietrudno wyobrazić sobie jako ozdobę dziecięcej sypialni - uszyto go z kilku rodzajów jasnej, pasiastej tkaniny, z przodu głowy umieszczając błyszczące guziki. Lalka nie daje szerokich możliwości animacyjnych, jej ruchoma szczęka otwiera się, ale nie „mówi”, tułów jest ciężki i nieelastyczny. Z kolei wąż toruński przypomina bohatera popularnej gry na telefony komórkowe w wersji 3D - ma jaskrawozielony kolor, dużą głowę i wielkie, umieszczone z przodu czaszki, lekko zezujące oczy. Jest animowany w powietrzu przez kilku aktorów i w żaden sposób nie przypomina budzących respekt gadów, jakie spotykamy w naturze.

Autorki obu sztuk starają się mówić o kwestiach ludzkich, antropomorfizując perspektywę swoich bohaterów. Niemniej zabiegi, jakie stosują, by „oswoić” niepopularne zwierzęta, mogłyby stać się punktem wyjścia dla interpretacji scenicznej, która nosiłaby znamiona empatii krytycznej w rozumieniu tego terminu przez Kari Weil (Weil 2014, 30). Celem żadnej z przytaczanych wyżej inscenizacji nie jest jednak skupienie uwagi odbiorcy na perspektywie węża lub gołębia ani działanie na rzecz dostrzeżenia przez człowieka ich specyficznych problemów czy potrzeb. Spektakle

8 Zapewne podobnie wydarzyłoby się w sytuacji, gdyby lalki gołębi z Teatru Animacji nie były „kolorowe, zabawne i przyjazne”. 
nie prowadzą także do rozpoznania w zwierzęcym doświadczeniu niedostępnej człowiekowi perspektywy „innego”, kogoś znajdującego się poza ludzkim doświadczeniem. W przytaczanych realizacjach niepopularne zwierzęta zostały sprowadzone do roli komicznych i przyjaznych kreatur, które zyskują sympatię widzów tym, że w małym stopniu przypominają swoje, występujące w naturze, pierwowzory.

\section{Niedźwiedzia przysługa wyświadczona entomologii}

Wśród zwierząt niepopularnych, obok uznawanych za brzydkie lub szkodzące człowiekowi, niewątpliwie znajdują się owady. Mało kto lubi „robale” i widzi potrzebę zgłębiania wiedzy na ich temat. O ludzkiej niechęci, odrazie, a często też ignorancji wobec tej gromady zwierząt przekonująco i z pasją pisał autor Pająków pana Roberta w przedmowie do swojej książki. Jednym z napiętnowanych przez Roberta Pucka utworów jest esej Zbigniewa Herberta Piekło owadów. Herbert nie tylko lekceważąco odnosi się w nim do przedmiotów fascynacji Jana Swammerdama, wybitnego siedemnastowiecznego entomologa, ale przede wszystkim myli jętkę jednodniówkę z łątką .

Jak się okazuje, nie tylko on. Jętka jest główną bohaterką sztuki Tylko jeden dzień Martina Baltscheita i w polskim przekładzie Lili Mrowińskiej-Lissewskiej występuje właśnie jako łątka. Podobna niefrasobliwość tłumaczki nie tylko stanowi dowód pobłażliwego traktowania przedstawicieli świata owadów, ale też wprowadza w błąd czytelników, pozbawiając ich poznania nazwy i zwyczajów insektów, które wczesnym latem często spotyka się przy zbiornikach wodnych. Jętkę poznajemy chwilę po przeobrażeniu w dorosłą postać, a świadkami tych „narodzin” są Lis i Dzik, którzy postanawiają uczynić jedyny (w ich przekonaniu) dzień życia ich nowej koleżanki możliwie najpiękniejszym. Oprócz faktu, że bohaterowie potrafią mówić i znajdują się w nieprawdopodobnej sytuacji z przyrodniczego punktu widzenia, autor zachował zwierzęcy charakter wszystkich postaci. Czytelnik dowiaduje się między innymi, że lis poluje na kury, by je zjadać, ale przede wszystkim poznaje zwyczaje jętek, które w dramacie Baltscheita okazują się fascynującymi stworzeniami. Zanim osiągną dojrzałość, mogą przeżyć kilkanaście miesięcy jako larwy, a ponieważ mają uwsteczniony układ pokarmowy, ostatni etap ich życia może trwać zaledwie kilka minut - w tym czasie dorosłe samice po zapłodnieniu przez samce składają jajeczka. To wszystko wynika z treści dramatu mimochodem, bo głównym tematem utworu są nieuchronność i naturalność śmierci, a także afirmacja życia. Kolejne sceny skrzą się od komizmu sytuacyjnego rozładowującego poważną wymowę tekstu, a całość składa się na świetnie napisany utwór sceniczny, w którym wyobraźnia i wiedza przyrodnicza autora harmonijnie dopełniają się z konwencją komedii dell'arte.

\footnotetext{
${ }^{9}$ Co, jeśli wierzyć Panu Robertowi, jest błędem większym, niż pomylenie Zbigniewa Herberta z Georgem Herbertem (Pucek 2014, 13). 
Sztuka Baltscheita doczekała się w Polsce dwóch realizacji lalkowych: na deskach Zdrojowego Teatru Lalek w Jeleniej Górze (reżyseria Agata Kucińska, scenografia i lalki Anna Chadaj) i w Państwowym Teatrze Lalek Tęcza w Słupsku (reżyseria Edyta Januszewska, scenografia i lalki Olga Ryl-Krystianowska). W spektaklu jeleniogórskim użyto dużych form: aktorzy grający Lisa i Dzika są ubrani w futrzane kostiumy, w jednej ręce trzymają głowę postaci, a drugą animują jej rękę. Mimo że ssaki poruszają się na dwóch nogach, są podobni do występujących w naturze pierwowzorów (rudy Lis ma puszystą kitę, Dzika wyposażono w kły, plastyczny, ruchomy ryj i brązowe futro). Lalka głównej bohaterki jest dużo mniejsza i niewątpliwie owadzia, lecz bardziej przypomina grubiutką muchę niż smukłą, delikatną jętkę. Jej, podkreślaną wielokrotnie w tekście, urodę w spektaklu przedstawiono, odwołując się do ludzkich kanonów kobiecego piękna. Jętkę-muszkę ubrano w falbaniastą, bladoróżową sukienkę, obdarowano ją dużymi owadzimi oczami i ponętnymi długimi rzęsami, którymi zalotnie trzepocze. W spektaklu ze Słupska mamy do czynienia z dużo mniejszymi animantami przypominającymi dziecięce maskotki lisa i dzika z doczepionymi gabitami ${ }^{10}$, zaś lalka głównej bohaterki to musza dziewczynka ubrana w białą sukienkę i niebieski berecik, wyposażona w parę sznurkowych rąk i nóg. Ku domniemanemu oburzeniu Pana Roberta, ta ostatnia w spisie postaci nie figuruje jako Jętka, ale... Muszka.

Nietrudno zauważyć tu tendencję, jaka pojawiła się już w realizacjach Dzioba $w$ dziób - formy dobrze znanych ssaków są do nich podobne, natomiast referencyjność lalki mało znanego zwierzątka należącego do niepopularnych owadów względem pierwowzoru została zlekceważona. Tym samym trudno pozbyć się wrażenia, że obie adaptacje odzierają tekst Baltscheita z tego, co stanowi o jego wyjątkowości. Współcześnie nie tak trudno jest znaleźć dobrze napisany dramat poruszający ważny i trudny temat uznawany w sztuce dla dzieci za tabu (śmierć niewątpliwie do nich należy). Natomiast utwory sceniczne, które zawierają informacje o życiu i cechach gatunkowych zwierząt niepopularnych, a jednocześnie nie są scenariuszami widowisk edukacyjnych, w Polsce właściwie nie powstają. Zarówno tłumaczka sztuki, jak i realizatorzy spektakli tak dalece zignorowali to, o jakim zwierzęciu napisał Baltscheit, że ich pracę entomolodzy mogliby potraktować jako niedźwiedzią przysługę.

\section{Baltic. Pies, który nie mówił ludzkim głosem}

Mówiące zwierzęta nie tylko w teatrze dla dzieci, ale też w szeroko rozumianej dziecięcej popkulturze są zjawiskiem tak powszechnym, że stają się oczywiste. Nawet jeśli to, co mówią, pozostaje zagadką dla ludzkich bohaterów historii, widzowie zazwyczaj rozumieją wszystko. Spektakl Baltic. Pies na krze na podstawie książki Barbary Gawryluk, który w 2012 roku w Teatrze

${ }^{10}$ Czyli krótkimi kijkami do animacji kończyn, tułowia i głowy. 
Miniatura w Gdańsku wyreżyserował Romuald Wicza-Pokojski równie dobrze mógłby nosić tytuł Baltic. Pies, który nie mówił ludzkim głosem. Widowisko jest nie tylko udaną próbą wprowadzenia do teatru dla dzieci nurtu nazywanego teatrem dokumentalnym. Przynosi także bezprecedensowe zderzenie perspektyw ludzkiej (granej w żywym planie) i zwierzęcej (tytułowy bohater jest realistyczną lalką, jedyną, jaka pojawia się na scenie).

$\mathrm{W}$ teatrze animowanych form użycie formy zwierzęcia nie jest niczym wyjątkowym - zarówno one, jak i antropomorfizowane przedmioty bywają bardziej atrakcyjne od bohaterów ludzkich. Wydają się naturalnym wyborem twórców teatru lalek zarówno z powodów historycznych czy praktycznych, jak również mają wymiar symboliczny. Aktor-człowiek sprawuje nad lalką-zwierzęciem władzę absolutną: poruszając animantem, nie tylko kontroluje każdy jego ruch i działanie, ale przede wszystkim daje i odbiera mu życie. Martwy przedmiot zmienia swój status ontologiczny zależnie od woli i działań człowieka. Jeśli obiekt ten jest wyobrażeniem zwierzęcia, ludzka władza nad światem zwierząt ucieleśnia się w formie tyle symbolicznej, co totalnej.

Opisana zależność nabiera szczególnej mocy w gdańskim spektaklu inspirowanym autentycznymi zdarzeniami ze stycznia 2010 roku. W końcu to ludzie zgotowali psu okrutny los, a ostatecznie także ocalili życie. Lalka Baltica, dająca się prowadzić zarówno przez jednego, jak i pięciu animatorów, jest konstrukcyjną perełką. Jej, składający się z ruchomych segmentów połączonych stawami, szkielet pozwala na realistyczną animację. Mechanizmy do manipulowania oczami i uszami czworonoga wzmacniają iluzję, a scena, w której psiak wycieńczony zamiera w bezruchu, wywołuje tym silniejszy efekt. Baltic, w którym w czasie ostatnich kilkudziesięciu minut widzowie rozpoznali żywą istotę, w ciągu sekundy zamienia się w martwy przedmiot. O tym, czy ponownie ożyje, decydują animatorzy.

Widzowie śledzący przebieg spektaklu stają się świadkami wyrwanych z kontekstu zdarzeń. Oto bawiące się na śniegu dzieci spotykają zabłąkanego kundla - boją się do niego zbliżyć, bo zwierzak może być chory; nie chce jeść ciastka podanego mu przez dziewczynkę, choć wygląda na głodnego. Te dzieci nie widziały, jak zwierzę wystraszone hukiem petard w noc sylwestrową zgubiło drogę do domu. Inna scena: dziennikarze na żywo relacjonują fragment psiej odysei, dopowiadając, że zwierzak prawdopodobnie na krze ucieka przed wyjątkowo złym właścicielem. Publiczność natomiast widziała moment wysadzania lodu na Wiśle - błądzący nieopodal przerażony pies skoczył na krę, a ta oderwała się i podryfowała z wartkim nurtem rzeki. Choć publiczność wie więcej niż bohaterowie spektaklu, obserwuje zdarzenia z własnej, ludzkiej perspektywy. Tej zwierzęcej może się tylko domyślać. Pies nie mówi ani się nie skarży. Czasem wyje, ale przede wszystkim trzęsie się z zimna, ślizga na lodzie, ucieka przed ludźmi nieudolnie próbującymi mu pomóc. Widzimy, jak jego serce bije coraz wolniej, z jakim trudem oddycha. 
Równie przejmujący, co jego losy, jest brak języka, który umożliwiłby pomoc psu. Ludzie są głupi w swojej bezradności i braku wyobraźni pozwalającej zrozumieć zachowanie zwierzęcia - w końcu w dobrej wierze rzucają w (do) kundla puszkami z karmą i kocami, a także krzyczą najgłośniej i najwyraźniej jak mogą, by skoczył do nich na brzeg. Kiedy w Gdańsku pies wypływa na pełne morze, na którym najprawdopodobniej zginie, żegna go orkiestra i media relacjonujące przebieg wydarzeń. Publiczność widzi kuriozalność tej sceny, a także czuje jej tragizm. Ostatecznie nikt tu celowo nie skrzywdził zwierzęcia. Po prostu nie udało się go uratować, bo nie można było się z nim porozumieć.

Na szczęście historia ma inne zakończenie. Ponad dwadzieścia kilometrów od brzegu psa dostrzegają członkowie załogi statku badawczego „Baltica”. Spuszczają na morze szalupę i w ostatniej chwili ratują życie zwierzaka. Tę akcję oglądamy przez oko kamery telefonu, którym zarejestrowano przebieg zdarzeń. Rozpoczyna się od dramatycznego krzyku: „Człowiek za burtą!”. Na niewyraźnym nagraniu wideo widzimy, jak pies wyślizguje się z rąk ratownika i wpada do wody, zanim ostatecznie zostanie wciągnięty na pokład. Następnie (już na scenie) członkowie załogi reanimują psa według procedur ratowania ludzkiego życia: masują go, okrywają kocami, poją ciepłymi płynami. Twórcy spektaklu przedstawili zwierzę jako stworzenie zdane na łaskę człowieka, zachowując jego odrębność, a jednocześnie znaczenie życia psa, stawiając je na równi z życiem ludzkim. We współczesnym teatrze dla dzieci jest to przypadek bezprecedensowy.

\section{Parę słów o infantylizacji}

Dokonany przeze mnie przegląd tekstów i niektórych ich realizacji nie wyczerpuje szerokiego tematu sposobów ukazywania zwierząt we współczesnym teatrze lalek dla dzieci. Badając to zagadnienie, należy wziąć pod uwagę możliwości wykonawcze teatru formy, metamorfozy kulturowe, jakim podlegają ssaki, ptaki, gady itp. na poziomie konstrukcji postaci, przyrodnicze spojrzenie pozwalające na porównanie występujących w naturze pierwowzorów z ich scenicznymi wyobrażeniami, a także zmiany zachodzące w podejściu do podmiotowości zwierząt.

O ile współcześni dramatopisarze dobierając protagonistów swoich sztuk, rzadko kierują się chęcią pogłębionej prezentacji ich charakterystycznych cech gatunkowych czy podjęcia dyskusji o granicach, sposobach i skutkach antropomorfizacji zwierząt, o tyle realizatorom spektakli w ogóle na tym nie zależy. Najlepszym tego dowodem jest sztuka o jętce jednodniówce. Cóż z tego, że autor zadał sobie trud, by poznać i opowiedzieć o zwyczajach tych owadów, skoro polski czytelnik i widz łatwo może przeoczyć informację, że właśnie o jętki, nie łątki tu chodzi? Jeśli nawet się tego dowie, na scenie nie zobaczy postaci dającej wyobrażenie rzeczywistego 
wyglądu jętki. Nadal będzie spotykał te owady nieświadomy ich niezwykłych zdolności, a nawet właściwej nazwy.

Uczłowieczanie zwierzęcych lalek teatralnych ma swoje praktyczne uzasadnienie, ale nie widzę usprawiedliwienia dla dowolności w projektowaniu ich podobizn. Lalka służy budowaniu iluzji. Oglądając spektakl teatru formy, dajemy się uwieść wrażeniu, że obserwujemy perypetie żywych stworzeń, jednocześnie wiedząc, że patrzymy na poruszane przez aktorów przedmioty. Aby uwierzyć w życie lalki, trzeba dostrzec i intuicyjnie zrozumieć ruch przez nią wykonywany, a ten z kolei najłatwiej odnieść do ludzkiej mowy ciała lub do zachowań dobrze znanych zwierząt. W budowie animantów najważniejsze są głowa i oczy - widz musi wiedzieć, gdzie lalka „patrzy”. To najbardziej znany mi powód, dla którego oczy lalek reprezentujących istoty poza-ludzkie są nienaturalnie duże i niemal zawsze umieszczone z przodu czaszki, na podobieństwo ludzkiej twarzy. Zasada ta dotyczy również sytuacji, w których lalki zwierząt skonstruowano z pedantyczną dbałością o ich realistyczny wygląd ${ }^{11}$.

Infantylizacja postaci zwierzęcych została naukowo objaśniona - napisał o tym Stephen Jay Gould w jednym z esejów zebranych w tomie Niewczesny pogrzeb Darwina. Ewolucjonista dokonał analizy metamorfoz, jakim rysownicy wytwórni Walta Disneya na przestrzeni półwiecza poddali postać Myszki Miki i szczegółowo przeanalizował zmieniające się wskaźniki procentowe dotyczące wielkości oczu i głowy czy wypukłości czaszki Mikiego, a także proporcji jego ciała. Patrząc z ewolucyjnego punktu widzenia, Miki im był starszy, tym dziecinniej wyglądał i się zachowywał. Szukając uzasadnienia dla tych zmian, Gould sięgnął do badań Konrada Lorenza, który twierdził:

charakterystyczne cechy wyglądu odróżniające dzieci od dorosłych pełnią u człowieka rolę ważnych bodźców behawioralnych. Uważa on, że cechy juwenilne odblokowują u dorosłych "wrodzone mechanizmy" skłaniające do serdeczności i opiekuńczości. Kiedy patrzymy na stworzenie obdarowane cechami dziecięcymi, automatycznie ogarnia nas fala czułości (Gould 1973, 261).

Małe dzieci nas rozczulają, małe zwierzęta także - jeśli więc chcemy, by bohater budził sympatię, powinniśmy wizualnie upodobnić go do niemowlęcia. Wymienione przez Goulda cechy, odróżniające ciało niemowlęcia od ciała dorosłego człowieka, jak: okrągła i nieproporcjonalnie duża w stosunku do reszty ciała głowa; duże oczy i mała szczęka; średniej wielkości tułów; pulchne nogi i ręce; małe dłonie i stopy, są również cechami, jakie posiadają teatralne lalki. Przeczucie Eco dotyczące powodów infantylizacji zwierząt wydaje się zatem trafne, a przynajmniej znajduje potwierdzenie w badaniach przyrodniczych.

${ }^{11}$ Mowa o spektaklu Odlot w reżyserii i scenografii Janni Younge z Teatru Animacji w Poznaniu. Pojawia się w nim kilkanaście form różnych ptaków: od bocianów, przez pelikany i flamingi, po marabuta. Wszystkie rozmiarami i konstrukcją do złudzenia przypominają swoje, występujące w naturze, pierwowzory, ale ich oczy umieszczono w taki sposób, by ptaki mogły „patrzeć dziobem”, czyli frontalnie. 
Trudno ocenić, na ile twórcy teatru dla dzieci infantylizując lub antropomorfizując zwierzęta, kierują się chęcią wzbudzenia sympatii względem nich, a na ile traktują je jako prosty zamiennik ludzkich postaci. Tymczasem gest użycia zwierzęcia zamiast człowieka najczęściej nie wystarczy, by zbudować wartościową metaforę. Zwłaszcza gdy u jej podstaw leży powierzchowna wiedza i przedmiotowe podejście do zwierzęcych postaci. Artyści nierzadko deklarują chęć poruszania ważnych społecznie tematów, rozbijania kulturowych klisz i ośmieszania stereotypów. Świat zwierząt pełen jest potencjalnych bohaterów takich historii, bo mnóstwo jest zwierząt, o których naturze niewiele wiemy. Najbardziej oczywistym przykładem są wilki. Niecierpliwie czekam na sztukę, której bohaterem będzie wilk bliższy Kazanowi lub Romeowi ${ }^{12}$, niż czarnemu charakterowi z baśni braci Grimm. Tymczasem autorzy przedmiotowo wykorzystując postaci ssaków, ptaków czy gadów, zupełnie nie zauważają, że utrwalają mity, z jakimi chcą walczyć. Sam gest bezrefleksyjnego traktowania zwierząt jako sympatycznych maskotek, przypisywania im cech, których nie posiadają, lub korzystania z klisz kulturowych na ich temat, jest wątpliwy etycznie, ponieważ omija okazję do rozmowy na ważny ekologicznie temat, a także karmi dzieci nieprawdziwymi informacjami, w zamian fundując im słabą rozrywkę.

Biorąc pod uwagę, jak bardzo najmłodsi są ciekawi świata i łatwo przyswajają nowe wiadomości, nieustannie zaskakuje powszechne przyzwolenie na prezentowanie im nieprawdziwych informacji. Treści, które - przekazywane dorosłym - uznalibyśmy za błędy rzeczowe, w sztuce dla dzieci nazywa się „przestrzenią dla wyobraźni” (zarówno autorów jak i odbiorców). Sprzeciw wobec podobnej praktyki nie znajdzie zrozumienia większości artystów, a walka z argumentami dotyczącymi rzekomego braku fantazji krytyka jest walką z wiatrakami.

\section{Bibliografia:}

Baltscheit Martin, 2012, Tylko jeden dzień, Mrowińska-Lissewska L. (przeł.), „Nowe Sztuki dla Dzieci i Młodzieży”, z. 34, Poznań.

Eco Umberto, 1993 Jak mówić o zwierzętach, w: Zapiski na pudełku od zapałek, Szymanowski A. (przeł.), Poznań, s. 66-71.

Falkiewicz Andrzej, 1968, Kilka myśli o teatrze dla najmłodszych, „Dialog” nr 11, s. 101-105.

Golachowski Mikołaj, 2016, Czochrałem antarktycznego słonia i inne opowieści o zwierzołkach, Warszawa.

Gould Stephen Jay, 1999, Biolog w hołdzie Myszce Miki, w: Niewczesny pogrzeb Darwina. Wybór esejów, Kancewicz-Hoffman N. (przeł.), Warszawa, s. 256-267.

Guśniowska Marta, 2012, Wąz, „Nowe Sztuki dla Dzieci i Młodzieży”, z. 33, Poznań.

${ }^{12}$ Pierwszy jest bohaterem Wilków Adama Wajraka, historię drugiego opisał Nick Jans w książce pt. Wilk zwany Romeo. 
Guśniowska Marta, 2016, Marvin, „Nowe Sztuki dla Dzieci i Młodzieży”, z. 40, Poznań.

Herbert Zbigniew, 1993, Piekło owadów, w: Martwa natura z wędzidłem, Wrocław.

Jans Nick, 2016, Wilk zwany Romeo, Pluszka A. (przeł.), Warszawa.

Jaremowa Zofia, 1952, Widz w teatrze lalek, „Teatr Lalek”, nr 9, s. 16-23.

Mikołuszko Wojciech, 2016, Zwierzęta drugiego sortu. Na ratunek brzydalom, „Gazeta Wyborcza” 21.06.

Prześluga Malina, 2009, Najmniejszy bal świata, „Nowe Sztuki dla Dzieci i Młodzieży”, z. 29, Poznań.

Prześluga Malina, 2010, Bleee..., „Nowe Sztuki dla Dzieci i Młodzieży”, z. 29, Poznań.

Prześluga Malina, 2013, Dziób w dziób, „Nowe Sztuki dla Dzieci i Młodzieży”, z. 35, Poznań.

Pucek Robert, 2014, Pająki Pana Roberta, Wołowiec.

Simberloff Daniel, 1998, Flagships, Umbrellas, and Keystones: Is Single-Species Menagement Passé in the Landscape Era?, „Biological Conservation” vol. 83, s. 247-257.

Wajrak Adam, 2015, Wilki, Warszawa.

Wiktorowska-Chmielewska Agnieszka, 2012, Malwinka w Ptasim Królestwie, „Nowe Sztuki dla Dzieci i Młodzieży”, z. 33, Poznań.

\section{Spektakle:}

Baltic. Pies na krze, reż. Wicza-Pokojski Romuald, scen. Waras Mariusz, Teatr Lalek Miniatura w Gdańsku, premiera 16.12.2012.

Dziób w dziób, reż. Lisowski Zbigniew, scen. Panas Dariusz, Teatr Baj Pomorski w Toruniu, premiera 23.06.2013.

Dziób w dziób, reż. Maciejewski Ireneusz, scen. Romanowicz Robert, Teatr Animacji w Poznaniu, premiera 17.04.2016.

Tylko jeden dzień, reż. Kucińska Agata, scen. Chadaj Anna, Zdrojowy Teatr Animacji w Jeleniej Górze, premiera 6.10.2013.

Tylko jeden dzień, reż. Januszewska Edyta, scen. Ryl-Krystianowska Olga, Państwowy Teatr Lalek Tęcza w Słupsku, premiera 23.09.2016.

Wą̇, reż. i scen. Zákostelecký Marek, Wrocławski Teatr Lalek, premiera 1.06.2013.

Wą̇, reż. Maciejewski Ireneusz, scen. Guzik Barbara, Teatr Baj Pomorski w Toruniu, premiera 23.03.2014.

Wą̇, reż. Ryl-Krystianowski Janusz, scen. Zagajewski Jacek, Teatr Animacji w Poznaniu, 18.05.2014. 


\section{O Autorce:}

Agata Drwięga - absolwentka Uniwersytetu im. Adama Mickiewicza w Poznaniu, kierunek wiedza o teatrze. W pracy badawczej zajmuje się współczesną dramaturgią dla dzieci i młodzieży ze szczególnym uwzględnieniem dorobku artystycznego Suzanne Lebeau oraz historią teatru dla dzieci. Współpracuje z pismami branżowymi „Teatr” i „Teatr Lalek”. Związana z poznańskim Teatrem Animacji i Centrum Sztuki Dziecka. 
